\title{
The Spanish Republican Exile: Identity, Belonging and Memory in the Digital World
}

\author{
Lidia Bocanegra Barbecho and Maurizio Toscano
}

\begin{abstract}
In recent years there has been an increasing number of websites dedicated to providing information about the Spanish Republican exile. These are generally created by exile descendants' associations, research groups or private individuals. The recent growth of social networks, especially Twitter and Facebook, has simplified the exchange of this information and allowed the culture of the Republican exile to spread through the Internet and beyond, also influencing the scientific literature on this topic. This paper aims to analyse how the memory of the exile has grown through the Web with the passing of time and to examine the channels of communication that have become places of identity and belonging for the exiles, creating and enhancing a culture that permeates not only communities interested in the subject, but also people not directly linked to it. At the same time, it also aims to lay the foundations, for the first time, for the study of the memory of the exile in the digital domain. We start by recounting the burgeoning creation of websites and social media groups devoted to the republican exile, from 1998 to 2015, and link it with both contemporary Spanish political events and an in-depth look at recent Twitter activity. We then move to a fresh look at the digitised literature in Spanish on this topic present in the Google Books corpus, and finish by exploring the results from an online survey
\end{abstract}

The original version of this chapter was revised. The erratum to this chapter is available at DOI 10.1007/978-3-319-29544-2_16.

L. Bocanegra Barbecho $(\square)$

Universidad de Granada, Granada, Spain

e-mail: lbocanegra@ugr.es

M. Toscano

Eachtra Archaeological Projects Ltd., Lickybeg, Clashmore, Co. Waterford, Ireland

e-mail: maurizio@eachtra.ie 
conducted in order to gain an insight into the motivations behind the increasing interest in the Spanish Republican Exile in contemporary global society.

1 Introduction

This paper aims to analyse how the memory of the exile has spread through the Web with the passing of time and to examine the channels of communication that have become places of identity and belonging for the exiles, creating and enhancing a culture that permeates not only communities interested in the subject, but also people not directly linked to it. In the last decade, websites, social network groups, and digital resources about the Spanish republican exile have increased significantly. The global nature of the exile itself fits very well with the Web, which has become widely used by individuals and groups related to this topic wishing to recover its historical memory.

Why this global character? The exile resulted from the republican defeat after the Spanish Civil War which lasted 3 long years (1936-1939). While the exile began early in the conflict, when the war fronts between republicans and rebels kept changing, the largest diaspora of peoples occurred over January and February 1939. As the Catalan front was falling during that hard winter, about 500,000 people crossed the border with France. Ranging from republican soldiers and officers, government officials, to women, children and the elderly, people travelled primarily on foot supported by only a few motor vehicles. The French Government improvised concentration camps on the beaches of Argeles-Sur-Mer, where most of them were placed. Shortly thereafter other camps were organized: Saint-Cyprien, Arles-sur-Tech, Barcarés, Bram, Gurs, etc.; not forgetting the French colonies in North Africa where the concentration camps of Morand, Suzzoni and Relizane, amongst others, were created to locate those exiles arriving by sea from Cartagena and Alicante. In September that same year World War II broke out. Many of the republican refugees could not escape overseas to Mexico, Chile and other Latin American countries, so they had to fight for a second time alongside the French government or for the resistance, while others perished in the Nazi death camps. ${ }^{1}$

Initially, the interest in recovering the memory of these exiles began within the walls of universities and associations of exiles, but then the Web gave voice to the interests of the anonymous exiles, internationalising the collective memory of this Spanish historical event and narrowing the gap between the people and the culture of exile. In other words: what started as a subject owned by historians and the family members of exiles, soon, thanks to the Internet, spread out organically and spontaneously throughout society, in the multitude of countries concerned by this phenomenon. Thus, the culture of the exile reached the common citizen, becoming more accessible.

Finally, this paper also aims to lay the foundations, for the first time, for the study of the memory of the Spanish republican exile in the digital domain. Unfortunately, due to space limitations in this chapter we cannot make a comparative

\footnotetext{
${ }^{1}$ To learn more about the republican exile see the following bibliographical list: http:// exiliadosrepublicanos.info/en/bibliography-exile
} 
analysis with the Spanish Civil War, which has an even stronger presence on the Internet and also generates great interest.

\section{The Republican Exile on the Internet}

\subsection{Methodology}

A workflow protocol involving several steps have been established to locate and describe those active websites and social networking pages that directly or indirectly deal with the republican exile, producing a wide range of qualitative and quantitative data to analyse.

1. We started with an existing list of 71 active webpages collected during the e-xiliad@s interactive project, ${ }^{2}$ run since 2010 by Lidia Bocanegra Barbecho, author of this chapter.

2. This list was supplemented with other sites mentioned by users who participated in an online survey conducted specifically for this analysis. However, of all the websites identified by the surveyed users, all but 12 were already included in the initial list. This is significant because it reinforces the importance of the e-xiliad@s list as a reference source for the republican exile.

3. This expanded list was then checked against new Web searches in Spanish, French and English.

4. Additional searches were performed against social network platforms, mainly Facebook and Twitter and to a lesser extent Google+, YouTube and Pinterest.

5. Once the complete list was defined, we proceeded to split it into two main groups. Firstly, websites and social network pages that focus exclusively or mainly on the republican exile, and secondly those that refer to this topic indirectly, dealing for example with the Second World War or with French and German concentration camps. The final list comprised 183 webpages, ${ }^{3}$ but for this analysis we will focus only on the first group, subsequently divided into two: 74 standalone websites and 36 social network pages.

6. Four main languages were used for the Web screening: Spanish, being the language spoken originally by the people involved in this historical event; Catalan, as primary language of an affected region; French, being the main host language of the diaspora; English, being a sort of lingua franca, widely used on the Web.

\footnotetext{
${ }^{2}$ The e-xiliad@s international project is dedicated to obtaining unpublished sources of Republican exile directly from the users themselves (http://exiliadosrepublicanos.info/). The material obtained within this project, and the data collection methodology developed, resulted in several publications on the theme of exile, including in the field of digital history (Bocanegra and Toscano 2015).

${ }^{3}$ For the full list please visit: http://exiliadosrepublicanos.info/en/links.
} 
7. For each of the selected websites we made an effort to find out the original date of publication on the Internet, in order to discern the frequency that new pages about this topic were created.

\subsubsection{Identifying Publication Dates and Languages}

A variety of methodologies and techniques have been used to identify the publication date of webpages on the list. In some case it has been fairly simple, sometimes it was necessary to combine several methods together, in few cases it has been impossible.

For Blogs we used the date of the first post in the archive. For Wikipedia pages the publication date is stated on the Page Information section. For standard websites with a proprietary domain, the publication date is sometimes given on the Home or About Us pages or in the footer section, but for the vast majority we had to rely on several online tools to read WHOIS data (Whois Domains Tools; Whois lookup; EURid): these identify the owner of a domain and the date of registration, which is generally quite close to the publication date. Another very useful tool in this process has been the Wayback Machine (Internet Archive) available on the Internet Archive website, which stores random copies of websites since 1996. Even if these snapshots cannot give an exact date of publication, at least they establish a close terminus ante quem. They have been used for all those websites that are a subdomain or a section within a more general webpage, as the WHOIS only provides data for the root domain. Examples of this kind of websites come from research groups or projects affiliated to universities (Exilio Network; Mostra bibliográfica; Spanish Music in Exile), foundations (Biblioteca del Exilio) or governmental institutions (Chemins de mémoire. L'internement; Ministerio de Cultura), among others. Finally, in some cases, it has also been useful to perform Google searches ${ }^{4}$ looking for news published on digital media regarding the creation of a particular page.

Sometimes websites change domains over their lifetime, increasing the difficulties of tracking down the publication date. For example, the Asociación para el exilio cultural español: Hamaika Bide Elkartea initially used the domain hamaikabide.org but then changed the extension to .eus, while the Centro Documental de la Memoria Histórica (Documentation Centre of Historical Memory) moved its root domain from mcu.es to mecd.gob.es ${ }^{5}$ due to the change of government and ministerial nomenclature in 2011.

In terms of social networks, in some cases we found pages registered on exile topics, but with little (Operació Stanbrook Facebook) or no (Interacción de los exilios) activity, probably in order to reserve a space for future exploitation.

\footnotetext{
${ }^{4}$ In Google, we used the Custom Range option available within the Search Tools to filter news from a specific period of time, then word sorting results by date.

${ }^{5}$ The actual website link changed from http://www.mcu.es/archivos/MC/CDMH/index.html to http://www.mecd.gob.es/cultura-mecd/areas-cultura/archivos/mc/archivos/cdmh/portada.html.
} 
Of the Facebook pages on the list, only the public ones had a visible publication date, while Public or Closed groups and Unofficial pages lacked this information. For Google+ we used the date of the first post, while Twitter profiles and YouTube channels normally show that info in the About section. It has been impossible to identify the publication date for the Pinterest pin-board ${ }^{6}$ about the republican exile (Pinterest).

To determine the language of social network pages we especially took into account the association, institution or person in charge, who normally also managed a website or a blog on the same topic, double checking such data against the language used in the page description. With regard to the content, the language of posts vary according to the source of the news published and comments based on their author. ${ }^{7}$

Finally, I would like to highlight that this is the first effort to conduct a study about how the republican exile is memorialised on the Internet, so there are no previous reference points and the literature is sparse.

\subsection{Analysis}

\subsubsection{Web Pages Dedicated to the Republican Exile}

Figure 1 below illustrates the rate of creation of active webpages on the Spanish republican exile. In total we have 74 webpages listed among those who either deal exclusively with the republican exile or who devote a large part of their site to it (Chemins de mémoire; Ministére De La Défense). Social networks have been excluded from this section.

As shown in Fig. 1, the republican exile appears on the Internet very early, with at least 4 pages online before 2000. Furthermore, the creation of new websites is uninterrupted, albeit with some variability, since the advent of the Web until today. Looking more closely, we can see that until 2006 there is little difference from year to year. Yet in 2008, after the publication in December 2007 of the Ley de la Memoria Histórica ${ }^{8}$ in Spain, there is an explosion in the creation of new websites on this topic. Almost $30 \%$ of all webpages listed here were created between 2008 and 2009. The following year, 2010, the rate of creation drops significantly, yet doubling from the pre-2007 frequency (an average of 4.5 new webpages per year versus 2.2).

\footnotetext{
${ }^{6}$ Pins are visual bookmarks and links back to the original site.

${ }^{7}$ This pattern is reflected on the e-xiliad@s project Facebook page (created in 2010 by Lidia Bocanegra) where general info is offered in Spanish, post and news are published in Spanish, French and English but the vast majority of the comments are in Spanish: https://www.facebook. com/exiliados.republicanos.

${ }^{8}$ The Law of Historical Memory (Ley 52/2007, 26th of December) was passed by the Spanish Parliament in 2007, under the mandate of the Prime Minister Jose Luis Rodriguez Zapatero. This Act includes the recognition of all victims of the Civil War (1936-1939) and the subsequent dictatorship of General Francisco Franco (1939-1975).
} 


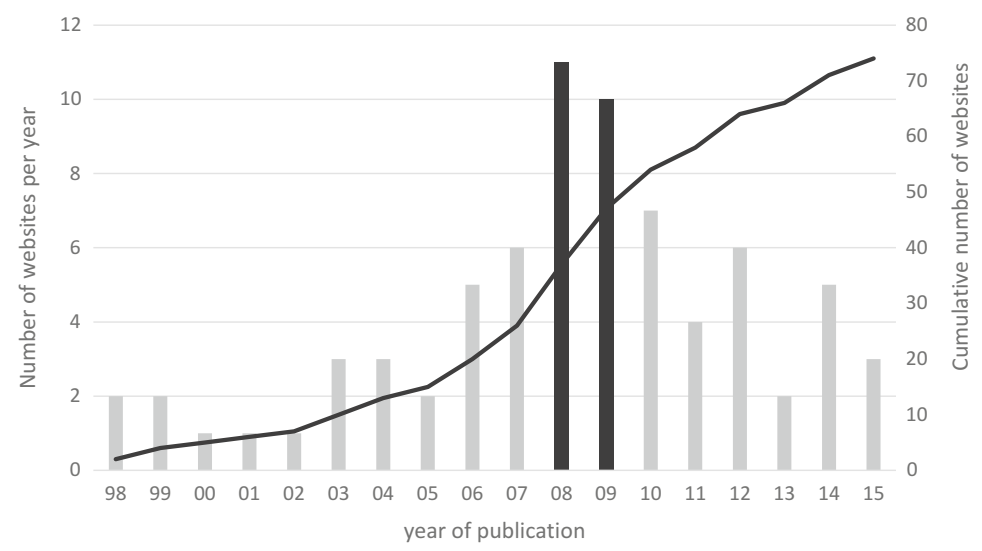

Fig. 1 Creation frequency of websites relating to the republican exile from 1998 to 2015, with cumulative curve. Source: compiled by the authors

Within this boom, eight pages are in Spanish, six in Catalan, five in French and only two in English. The preponderance of websites from Spain in this period strengthens the connection that can be inferred with the implementation of the above mentioned Law of Historical Memory: either as an influence coming from the spirit of the law or in terms of financial support from the government to carry out research projects on that subject. The vast majority of these websites are monolingual, with just $13.5 \%$ having more than one language. In order of representation, ${ }^{9}$ the Spanish language includes 44 pages, followed by 21 in French, 14 in Catalan, 11 in English and 1 each in German, Basque and Galician.

Out of a total of 74 websites analysed here, 50 had their own domain or subdomain, 19 were blogs and 5 Wikipedia pages.

Website blogs can be divided into several categories. Many are primarily designed to disseminate a specific topic about the exile and offer photographs, audio-visual material and documents with a purely didactic purpose (Art, Mémoire et Exil; Operació Stanbrook). Other blogs are essentially biographical (Diari d'un exiliat) and, from the point of view of microhistory, offer valuable and unpublished information about the anonymous exile. Finally, those from associations and forums for the cultural memory, generally inform readers about related cultural events, publications, conferences, seminars, celebrations and commemorative field trips.

Websites with their own domain or subdomain can belong to three groups: associations, institutions or private people. The first ones (Fills i nets; Association Retirada 37; FFREEE), generally managed by descendants of exiles, often provide very similar information to blogs belonging to associations.

Webpages belonging to academic institutions, which offer information about research projects (Spanish Music in Exile), exhibitions, conferences and

\footnotetext{
${ }^{9}$ To calculate percentages, multilingual web pages have been counted many times as languages available.
} 
publications, have a scientific rather than informative approach (Exilio Network). Non-academic institutional sites are mostly thematic (Chemins de mémoire. L'internement), or dedicated to providing archival sources, acting as important repositories for specific exile topics (Ministerio de Cultura).

Private sites vary a lot from specific to generic subjects, but often become valuable repositories of precious unpublished information about the diaspora and the anonymous exile (e-xiliad@s; Espagne au Coeur). These kind of websites are generally managed by specialists: historians or relatives of exiles very involved in collecting and publishing information about the republican exile.

\subsubsection{Social Network Pages Dedicated to the Republican Exile}

This section is focused on examining social network platforms like Facebook and Twitter as well as Google+, YouTube and Pinterest. We compiled a list of 36 pages about the republican exile: 17 on Facebook, 12 Twitter profiles, 3 Google+ pages, 3 YouTube channels and 1 Pinterest pinboard. Most of the Facebook pages are public so their content is accessible to anybody, while the seven public (Buscando a hij@s y niet@s) and closed (Mapa Colaborativo) groups require a Facebook account.

Figure 2 shows that the creation of webpages about the Spanish exile on social networks became significant in 2010 , since before that date we found just two examples.

Social networks are increasingly used by institutions, private associations and individuals interested in spreading the memory of the exile, attracted by the ease of use and sharing potential of these new platforms. Sometimes these social pages become more popular than existing websites managed by the same people, and can then attract the main flow of information. ${ }^{10}$

In terms of languages, ${ }^{11}$ Spanish is again, as expected, the majority with 28 pages, followed by Catalan and French with 4 pages each.

\subsubsection{All Together: Websites and Social Networks}

Considering both websites and social network pages together, we can clearly see in Fig. 3 that the pace of new sites creation stays almost steady between 2008 and 2014. As the number of new websites wanes, social network pages increase, showing a growing interest in disseminating this topic to a wider audience and recovering the memory in a different, more social way. Looking at the whole Web, the previously described boom extends until 2011, when the pace drops in an interesting correlation with the change from socialist (PSOE) to centre-right government in Spain (Partido Popular).

\footnotetext{
${ }^{10}$ An example is the Asociación de Descendientes del Exilio Español (Association of Descendants of Spanish Exile) that, despite having their own website, use YouTube, Google+, Facebook y Twitter to publish the main flow of information.

${ }^{11}$ For Facebook pages, we took into account the language specified in the section About.
} 


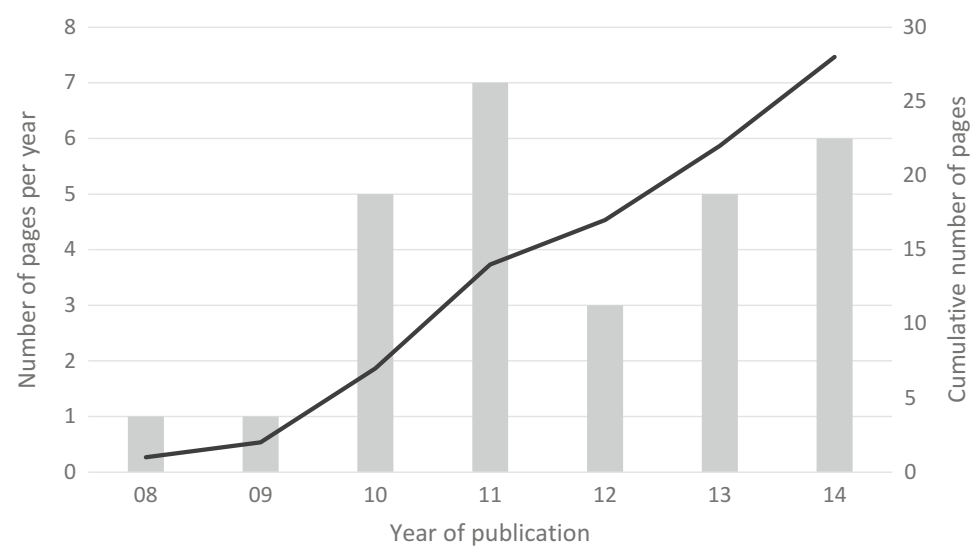

Fig. 2 Creation frequency of social network pages about republican exile from 2008 to 2014, with cumulative curve. Source: compiled by the authors

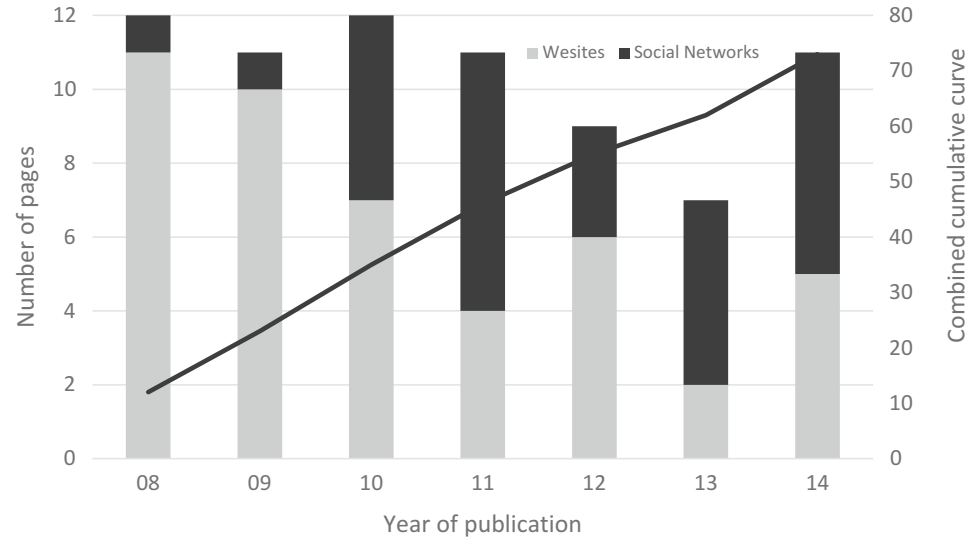

Fig. 3 Combined graph of creation frequency of new websites and social network pages from 2008 to 2014, with cumulative curve. Source: compiled by the authors

The growing interest in the republican exile on the Web, observable in the cumulative curve of Fig. 3, runs parallel with the subject of the Spanish Civil War (1936-1939). Indeed, a recent study (Eiroa 2014), shows that the civil war is still very popular in digital media, illustrating that the Internet is the most successful means to spread educational, cultural, informational, political and social material. ${ }^{12}$

The presence of the Spanish republican exile on the Web roughly follows the widespread growth of websites and social networks. As we have seen, the first

\footnotetext{
${ }^{12}$ This study provides a partial analysis of the Spanish Civil War on the Internet because, as indicated by the author, it analyses only four Spanish digital newspapers and other blogs, websites and social networks often without specifying them.
} 
pages on this historical phenomenon were published in the late 1990s, in parallel with the outset of the Internet in Spain or France: before 1998 the Internet was used in these countries on a monthly basis by less than $3 \%$ of the population (Eurostat; AIMC). In a similar way, the first page on social networks analysed here appears in 2008, the same year that Facebook was translated in Spanish and French (Wikipedia).

\subsubsection{Twitter Activity}

Social networks are increasingly becoming primary sources for social research. Among them, Twitter is taking a leading role, because with its hashtag norms, consistent length ( $\leq 140$ characters) and more accessible application programming interface (API), it is easier to gather, sort and search when collecting data. Several tools have been developed to help the researcher but we will limit our focus here on a qualitative assessment of tweets relating to the republican exile and a visual representation of their geographic provenance.

For this study we collected tweets about 'exilio republicano' and 'exiliados republicanos' over a period of almost 3 months between June and August 2015. ${ }^{13}$ We gathered a total of about 300 tweets of various type: news sharing, retweets and original comments. In the timeframe analysed, the visits of Felipe VI to Paris and especially to Mexico produced a lot of activity on Twitter, because the monarch commented on the republican exile in these countries. $80 \%$ of the tweets related to these visits were just news sharing, the rest were personal comments, mainly critical. Other events that produced Twitter activity were a documentary about the republican exile in northern Africa, a paper about Mexico, a documentary about the Maginot Line presented by the Spanish national broadcaster in mid-July and the survey implemented for this study: none of these produced a lot of original content from the users. In general, the activity on Twitter relating to the republican exile seems to be more focused on sharing news rather than on personal thoughts and opinions about related events.

An image is worth a thousand words, so taking advantage of a new feature available on the CartoDB platform (CartoDB), we decided to visualize this activity on a map. As mentioned earlier in this chapter, the republican exile is a historical event that affected several countries so we hypothesised that it would be worthwhile to visualise the relative location of collected tweets. Fig. 4 confirms that the exile remains a global phenomenon today, with Twitter activity from 17 countries, spread across several continents. The most prolific countries, as expected, are Mexico and Spain; while other less anticipated countries like USA, Brazil and even Armenia and Australia are also represented.

\footnotetext{
${ }^{13}$ We performed searches in French and English as well, but the results were so scarce that we decided to exclude them from this analysis. Moreover, some tweets from French users use the Spanish words to refer to this topic.
} 


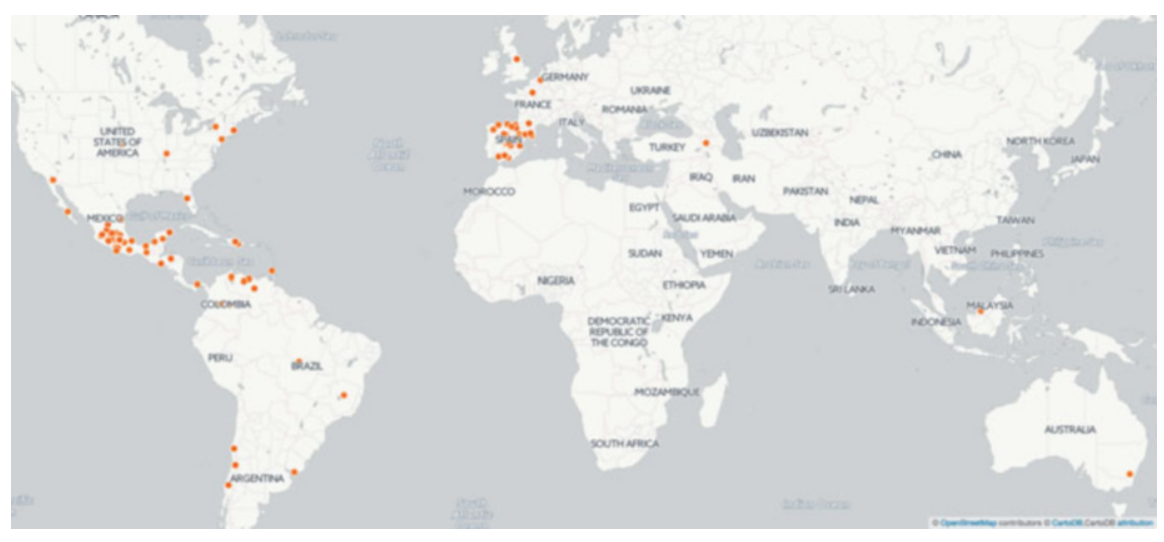

Fig. 4 Visualization of the geographic provenance of the Twitter activity related to the Spanish republican exile in the period June-August 2015. Source: compiled by the authors on CartoDB platform

\subsubsection{Google N-Gram Analysis}

Does the Internet have something to do with the increase of Spanish-language literature relating to the republican exile that appears from the end of the 1990s? The republican exile is a global phenomenon that connects people from disparate geographic locations and links them back to the origin of this historical event, Spain. The Web drastically shortens these distances, with the power to turn a worldwide phenomenon into something deceptively local. The increasing number of websites and social network pages on the republican exile is largely due to its international nature that perfectly fits with the Web. Using Google Books Ngram Viewer (VV. AA. 2011) we examined the frequency of the words (or n-grams) "exilio republicano" in books written in Spanish for the period from 1930 to 2008 (Fig. 5). In other words, we looked for the frequency of the republican exile topic in this literature. The most recent numbers found show more than eight million volumes digitised in Google Books, of which about 855,000 are in Spanish, the second largest corpus after English (VV.AA. 2012). We also included in the analysis the Spanish Civil War, because it is a closely related topic and an established subject in literature since 1936.

The republican exile appears in traditional books right after the death of dictator Francisco Franco (1975) and its presence grows very slowly until the end of the 1990s, when a relatively significant increase is recorded. This sudden rise in the literature coincides with the first websites dedicated to this topic, as seen in Fig. 1. We hypothesise here that with the advent of the Internet at the end of the 1990s, the topic of the republican exile takes on new life thanks to the Web's information sharing over long distances. This new wave of awareness goes beyond the digital sphere and is reflected in new printed books since the late 1990s. 


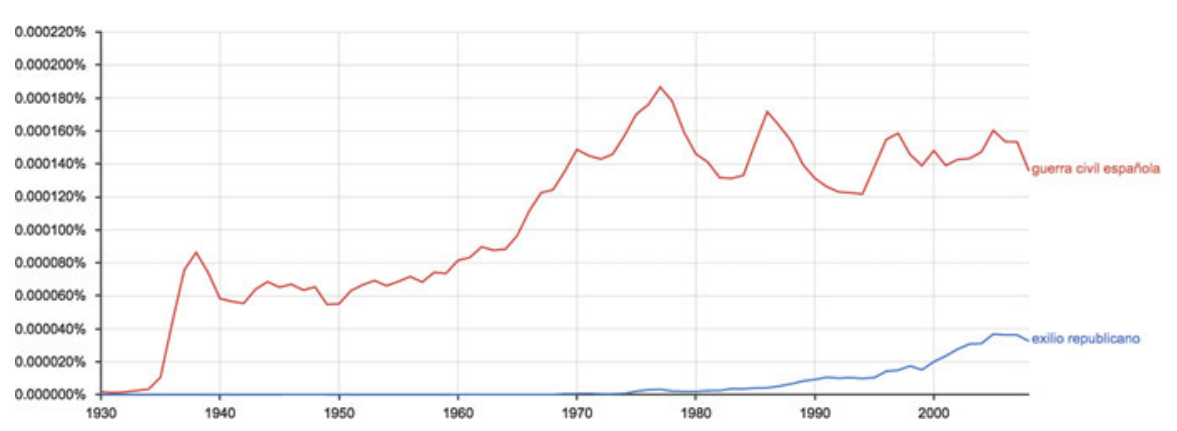

Fig. 5 Chart showing the presence of the republican exile and the Spanish Civil war in the Spanish corpus of Google Books. Source: Google Books Ngram Viewer

\section{Identity, Belonging and Memory: The Online Poll}

\subsection{Methodology}

In June 2015 we carried out an online survey in order to obtain qualitative data about users interested in the Spanish republican exile. The aim was to look at the pattern of behaviour of these users on the Web, including such things as which websites they visit and why.

The survey was conducted in three languages: Spanish, English and French and remained open online for a month from its start date on June 16, 2015. It was publicised in the three relevant languages on websites, mailing lists and social network groups, with the latter being the most effective. Overall the survey was sent to about 60 web pages and social networking sites focused on the republican exile or related topics. Posts were also added to online projects (e-xiliad@s) and academic channels: GrinUGR (GrinUGR) and Academia (Academia). Throughout the month, a new round of dissemination was held as a reminder, focused especially on previously contacted Facebook pages.

The survey (Survey) was divided into three parts with relative sub-sections, six of which were mandatory:

1. Personal data
(a) Name*
(b) Surname*
(c) e-mail*

2. Relationship with the Spanish republican exile

(a) What relationship do you have with the Spanish republican exile*?
i. Exiled
ii. Family of exiled
iii. Researcher/student of the exile
iv. Interested in the exile 
(b) If you're just an interested person about the republican exile: what is it that attracts you about it?

3. Web pages about the republican exile

(a) Which of these websites about the republican exile you have visited?*

(b) In case you usually check other sites not listed here, please specify which ones.

(c) Why do you visit websites about the republican exile?*

i. due to a feeling of belonging to a group

ii. because you feel identified with the exile

iii. because you can share ideas about the exile

iv. to know people close to your ideas and principles related to exile

$\mathrm{v}$. because in that way you think that the memory of republican exile recovers

vi. looking for information and to be updated on the latest news about the exile

vii. OTHER

(d) In case of "other", please specify

For questions 2(a), 3(a) and 3(c) the user had the possibility to select more than one answer. In 3(a) we added a list of 36 websites dedicated to the republican exile to choose from, also leaving the option to the end user to indicate other sites. In general, we focused on creating a concise survey that was easy for respondents to complete.

\section{$3.2 \quad$ Outcomes}

While expecting greater participation, ${ }^{14}$ we received a significant number of responses, 186 in total with 182 in Spanish, 2 in French and 2 in English.

Users were mainly relatives of exiles $(63.2 \%)$, while $6.5 \%$ say they are exiles themselves. Although not stated, the latter most likely be children or relatives of exiles, in fact some of them have also marked the option 'family of exile'. It is noteworthy that, based on age and familiarity with the Internet, it was unlikely that actual exiles could participate in the survey.

The remaining audience was made up by 51 researchers, 14 of which were also relatives of exiles, and 44 people interested in the topic. This last group gave a variety of reasons to explain their interest: having had direct contact with the exiled in countries such as Bulgaria, Cuba, Chile and Mexico; close proximity with people deported to Nazi concentration camps; professional, intellectual or literary connections; or reasons related with memory recall, as indicated by a person who

\footnotetext{
${ }^{14}$ For example, on the Facebook page of the e-xiliad@s project alone, with 464 followers to date July 29, 2015, the poll reached 655 people through 11 share and it was then published on other Facebook pages with many followers, i.e. Eco Republicano with 56k to date July 29, 2015.
} 
wrote: "I'm interested in terms of historical memory, social justice, vindication and denunciation of the past" (M.C.A.). In fact, almost all the groups quote the interest in recovering memory.

Regarding the websites listed in the survey and most visited by users, the following should be highlighted:

- Asociación de Hijos y Nietos del Exilio Republicano: 111 mentions

- Asociación de descendientes del exilio español: 87

- Guerra Civil española y Exilio Republicano: 68

- Españoles deportados a Campos de Concentración Nazis 1940-1945: 51

- Amical de Mauthausen y otros campos y de todas las víctimas del nazismo en España: 50

- Biblioteca Virtual Miguel de Cervantes-Biblioteca del Exilio: 49

- El barco del exilio: 49

- Fils et Filles de Républicains Espagnols et Enfants de l'Exode (FFREEE): 48

- Niños de Morelia: 48

-Proyectoe-xiliad@s: 45

- Los niños que nunca volvieron. Españoles emigrados en tiempos de guerra: 45

- MUME: Museu Memorial de l'Exili: 38

- Centro de Estudios de Migraciones y Exilios (CEME): 36

As shown, the most visited websites are those belonging to associations of descendants of the exile, a correlation with the biggest group of respondents. Other quite popular sites are those focused on offering information, acting as repositories and those on Nazi concentration camps.

Among those websites suggested by the users but not listed on the survey three stand out: Asociación para el estudio de los exilios y migraciones ibéricos contemporáneos (AEMIC), Asociación para la recuperación de la Memoria Histórica (Memoria Historica) and Basque children of '37 (Basque Children).

When asked for the reasons they visit such websites, $68.1 \%$ of all respondents expressed an interest in memory retrieval, and $50.3 \%$ to look for information and be updated about the topic, just under $20 \%$ chose the last one as the only reason.

Of all respondents, $44.9 \%$ say they identified with the exile ${ }^{15}$ while $36.8 \%$ visit this kind of websites due to a sense of belonging to a group. ${ }^{16}$ One of the respondents that specified a sense of belonging to a group, responded to the question of why visit the websites about the republican exile, saying: [I visit] "because of a loving feeling of being part of my father's story who lived during the Spanish republican exile to France. I lived his memoirs beside him... they are indirectly part of my life too. I learned to share his political and social ideas as an out-and-out Republican and I join the recovery of this historical memory to make

\footnotetext{
${ }^{15}$ For example, one respondent says that his father was exiled and because of this he has a special feeling with Spain (C.F.C.).

${ }^{16}$ Of all people that marked the option of belonging to a group, just $3.3 \%$ chose this option alone.
} 
justice. I would love to be in Spain and participate in some way in this great work. Thanks, thanks, thanks." (A.N.C.).

While both identification and belonging are comparable motives, a subtle difference lies between them. For example, it is possible that those exiled or their descendants identify themselves with this specific historical event, without necessarily being part of a group sharing ideas and memories. Let us remember that many women left Spain to be with their families and not necessarily due to professed political ideology. We are reminded of this by one of respondents, who commented: "I was raised by my grandmother who left a deep mark on me and, although it sounds like a paradox, it was her husband that was the republican, but she decided to follow him into exile" (A.G.B.). Sometimes the integration with the culture of the host country was such that, although the arrival was the result of a forced exile, it did not create the need to belong to any other group.

$28.1 \%$ of respondents visit those sites to find people with similar ideas and principles, while $25.4 \%$ stated the more general reason of sharing ideas about the republican exile, even if many people chose both along with other motivations such as memory retrieval, or the feelings of belonging to a group. Comments have been offered both by the descendants of exiles and researchers with the common thread of recovering the past: "I think we should recover those stories to do justice in memory of those who deserve it", says J.G.M.

\section{Conclusions}

In recent decades, stakeholders in the republican exile have seen the Internet as an excellent tool to disseminate and exchange information. Blogs and social networks have more and more become tools of expression and spaces of identity. A common goal is evident: recover the past with an emphasis on collective memory. Events such as the 1939 diaspora to France, the arrival in Mexico or the concentration camps are subjects that are shared, analysed and discussed, creating an online collective memory, leading to new social and sharing networks. It seems that now that the memory of the republican exile has moved to the Internet, it has been internationalised more than ever and it is influencing people who had no direct relationship with it. The impetus behind all these sites is connected to the descendants and researchers who have created a new dynamism for understanding and disseminating this subject. Such is the influence of the Web on this topic that we think it has influenced production in printed publications as well.

The process of recovering the collective memory of republican exile has received a strong boost with the implementation of the Law of Historical Memory by the Spanish Government, enacted in December 2007. On the Web, this translates into a period of increased creation of new websites between 2008 and 2011, of which most are in Spanish. The steady increase of pages on this subject, along with social networks starting from 2008, shows an on-going interest in spreading the reality of the republican exile through modern digital media. 
The families of exiles, direct heirs of their culture, feel identified within these digital places, many considering them communities that they belong to. Some webpages are more influential than others, especially those more active and with larger channels for outreach, thus leading to a wider audience. This strong connection with those families fosters the sharing of information, especially unpublished and historically valuable private documents.

Research groups, university projects and libraries as well have quite a large presence on the Web with regard to this research topic, both with websites of large institutions or private researchers. The academic footprint is rather lost in social network groups, where researchers share and discuss informally with exile descendants or simply amateurs in this field, wide-spreading scientific knowledge.

The Internet has become the panacea of the anonymous exile, a voice for those who were not famous intellectuals, artists or politicians, giving them a name and sometimes a face. Thousands of photographs circulate on the Web through these digital channels: many taken out from the drawers of relatives rather than from institutional archives. In these identificatory communal spaces, collective memory about a past event that still remains unresolved and continues to create tensions also seeks acknowledgment.

"[...] The drama lived in my family, the silence and the forgetfulness of that period still lingers. The exile, the forced uprooting because of war and the following forgetting of a whole generation are really tragic events, so difficult to visualize!" (N.T.B.).

Open Access This chapter is distributed under the terms of the Creative Commons AttributionNoncommercial 2.5 License (http://creativecommons.org/licenses/by-nc/2.5/) which permits any noncommercial use, distribution, and reproduction in any medium, provided the original author(s) and source are credited.

The images or other third party material in this chapter are included in the work's Creative Commons license, unless indicated otherwise in the credit line; if such material is not included in the work's Creative Commons license and the respective action is not permitted by statutory regulation, users will need to obtain permission from the license holder to duplicate, adapt or reproduce the material.

\section{References}

Academia. Retrieved August 4, 2015, from https://www.academia.edu

AEMIC. Migraciones \& Exilios. Cuadernos De La AEMIC-Asociación para el estudio de los exilios y migraciones ibéricos contemporáneos. Retrieved August 4, 2015, from http://www. aemic.org.

AIMC. Asociación para la Investigación de Medios de Comunicación—Audiencia De Internet En El EGM. Retrieved July 17, 2015, from http://www.aimc.es/-Audiencia-de-Internet-en-elEGM-.html.

Art, Mémoire et Exil. Retrieved July 15, 2015, from http://artmemoireexil.blogspot.com.es/

Association Retirada 37. Retrieved July 15, 2015, from http://retirada37.com/

Basque Children. Basque Children of ' 37 Association UK. Retrieved August 5, 2015, from http:// www.basquechildren.org/ 
Biblioteca del Exilio. Fundación Biblioteca Virtual Miguel de Cervantes. Retrieved July 10, 2015, from http://www.cervantesvirtual.com/bib/portal/exilio/

Bocanegra Barbecho, Lidia, and Toscano, Maurizio. (2015). El exilio republicano español: estudio y recuperación de la memoria a través de la web 2.0. Nuevo enfoque metodológico con el proyecto exiliad@s. In Migraciones \& Exilios, $\mathrm{N}^{\circ}$ 15, Ed. Asociación para el Estudio de los Exilios y Migraciones Ibéricos Contemporáneos, 2015. ISSN 157-3256.

Buscando a hij@s y niet@s. Buscando a hij@s y niet@s del exilio republicano. Retrieved July 12, 2015, from https://www.facebook.com/groups/173551176875/?ref=br_rs

CartoDB. Twitter Maps-CartoDB. Retrieved August 20, 2015, from https://cartodb.com/cartodbfor/twitter-maps/

Chemins de mémoire. L'internement : Camps Dans Les Pyrénées-orientales (66). Retrieved July 12, 2015, from http://www.cheminsdememoire.gouv.fr/fr/camps-dans-les-pyrenees-orientales-66.

Chemins de mémoire. Ministère De La Défense. À La Découverte Des Hauts Lieux De Mémoire. Retrieved July 12, 2015, from http://www.cheminsdememoire.gouv.fr.

Diari d'un exiliat. L'exili de Ramón Moral i Querol narrat per ell mateix. Retrieved July 15, 2015, from https://dietarideramonmoral.wordpress.com

e-xiliad@s. Spanish Republican Exiles. Retrieved July 29, 2015, from http:// exiliadosrepublicanos.info.

EIROA, Matilde. (2014). La Guerra Civil Española en la actualidad cibermediática. In Studia Historica. Historia Contemporánea, [S.1.], v. 32, pp. 367-368, ISSN 0213-2087. Retrieved August 3, 2015, from http://revistas.usal.es/ revistas_trabajo/index.php/0213-2087/article/ view/12540.

Espagne au Coeur. Guerre D’Espagne 1936-39—Guerra Española 1936-39. Retrieved July 15, 2015, from http://espana36.voila.net/index.htm.

EURid. The Registry for .eu Domain Names. Retrieved July 15, 2015, from http://www.eurid.eu.

Eurostat. Your key to European statistics. Retrieved July 16, 2015, from http://ec.europa.eu/ eurostat.

Exilio Network. Research into refugees and other migrations. Retrieved July 16, 2015, from http:// www.southampton.ac.uk/exilio.

FFREEE. Fils et Filles de Républicains Espagnols et Enfants de l'Exode. Retrieved July 15, 2015, from http://www.ffreee.typepad.fr.

Fills i nets. Fills i nets de l'exili republicà a Mèxic. Mexicans a Catalunya. Retrieved July 15, 2015, from http://exiliorepublicano.net/mexicans-a-catalunya/

Google Books Ngram Viewer. Retrieved August 5, 2015, from https://books.google.com/ngram

GrinUGR. Collaboratory for digital cultures in social sciences and humanities. Retrieved August 2, 2015, from http://grinugr.org.

Interacción de los exilios. Interacci on de los exilios en México e Iberoamérica. Retrieved July 12, 2015, from https://www.facebook.com/pages/Interacción-de-los-exilios-en-México-eIberoamérica-Siglo-XX/782863028392180?fref $=\mathrm{ts}$

Internet Archive. Internet archive: Wayback Machine. Retrieved July 4, 2015, from https:// archive.org/web

Mapa Colaborativo. Mapa Colaborativo del Exilio (Exile collaborative map). Retrieved July 13, 2015, from https://www.facebook.com/groups/exiliomexico/?fref=ts

Memoria Histórica. Asociación para la recuperación de la Memoria Histórica. Retrieved August 5, 2015, from http://memoriahistorica.org.es/

Miguel de Cervantes. Biblioteca Virtual Del Exilio. Retrieved July 12, 2015, from http://www. cervantesvirtual.com/bib/portal/exilio.

Ministerio de Cultura. Españoles Deportados a Campos De Concentración Nazis 1940-1945. Ministerio de Cultura. Retrieved July 15, 2015, from http://pares.mcu.es/Deportados/ servlets/ServletController?accion $=2 \&$ opcion $=10$.

Mostra Bibliogràfica. Mostra Bibliogràfica: L'Exili (1939-1975). Retrieved July 14, 2015, from http://crai.ub.edu/ca/coneix-el-crai/biblioteques/biblioteca-pavello-republica/exili.

Operació Stanbrook Facebook. Retrieved July 18, 2015, from https://www.facebook.com/profile. php?id=100006266836585\&fref $=$ ts 
Operació Stanbrook. Retrieved July 18, 2015, from http://www.operaciostanbrook.org/

Pinterest. EXILIADOS. Retrieved July 5, 2015, from https://es.pinterest.com/jorgeartajo/exiliados Spanish Music in Exile. University of Glasgow. Retrieved July 14, 2015, from http://www.gla.ac. uk/schools/cca/research/music/projectsandnetworks/spanishmusicinexile/

Survey. Survey: The Republican exile on the Internet. Google Docs. Retrieved August 3, 2015, from http://goo.gl/forms/kAvDLHsFST.

VV. AA. (2011). Quantitative analysis of culture using millions of digitized books. Science, 331, 176-182. doi:10.1126/science.1199644. Retrieved August 5, 2015, from http://www. sciencemag.org/content/331/6014/176.abstract.

VV. AA. (2012). Syntactic annotations for the Google Books Ngram Corpus. In Proceeding ACL '12 Proceedings of the ACL 2012 System Demonstrations, Association for Computational Linguistics Stroudsburg, PA. Retrieved August 5, 2015, from http://dl.acm.org/citation.cfm? id $=2390499$.

Whois Domain Tools. Domain availability \& IP search. Retrieved July 14, 2015, from http:// whois.domaintools.com.

Whois lookup. Retrieved July 14, 2015, from http://www.whois.com.

Wikipedia. Retrieved July 10, 2015, from https://fr.wikipedia.org/wiki/Facebook 